\title{
The Role of TMEM127 in mTOR Pathway and Cancer Suppression
}

\author{
Qi Wang ${ }^{1}$, Kun Wang ${ }^{1}$
}

\author{
${ }^{1}$ Institute for Translational Medicine, Qingdao University, Qingdao 266071, China
}

\begin{abstract}
Transmembrane Protein 127 (TMEM127), also known as FLJ20507, mutated in pheochromocytomas and renal cancers. The current study found that TMEM127 is widely distributed, versatile and closely related to the occurrence of disease. In this article, We summarize the function of TMEM127 in the signaling pathway and its impact on disease in detail. In the mTOR signaling pathway, TMEM127 regulates cell growth and proliferation, and acts as a tumor suppressor to inhibit tumorigenesis. Moreover, it can be used as a diagnostic indicator in pheochromocytoma and hereditary paraganglioma-pheochromocytoma syndrome. In addition, we have integrated the current clinical data and monitoring methods. This will provide ideas for further exploration of the function of TMEM127 and also provide a basis for the diagnosis and treatment of related diseases.
\end{abstract}

Keywords: TMEM127, mTOR Pathway, Pheochromocytoma, Paraganglioma

\begin{abstract}
Introduction
TMEM127 (transmembrane protein 127) is located on chromosome 2. It is a protein-coding gene whose coding sequence contains four exons, the first of which is not encoded. This gene is predicted to encode a transmembrane protein with three highly conserved transmembrane domains, but no identifiable functional motifs. TMEM127 can see highly homologous sequences in different species in mammals to fish, but it is not clearly recognized in invertebrates. Like humans, we found that mouse Tmem127 transcripts are expressed in different tissues and are expressed at different developmental stages [1]. TMEM127 is mostly localized to the plasma membrane, such as cell membrane and multi-pass membrane protein $[1,2]$. In addition, it also appears in the cytoplasm. Binding of TMEM127 to the cell membrane is enhanced by inhibition of endocytosis. In the cytoplasm, it colocalizes with early endosomal structures such as Golgi and lysosomes [1,2]. Yuejuan Qin et al. believe that TMEM127 binds dynamically to the inner body and may be involved in protein transport between the plasma membrane, Golgi and lysosomes [1].
\end{abstract}

\section{TMEM127 participates in the mTOR pathway}

mTOR (mammalian target of rapamycin, mTOR) is a kind of silk/threonine kinase[3, 4]. Although its C-terminal is homologous to the catalytic domain of phosphatidylinositol kinase (PI3K), it does not have the activity of esterase kinase itself, but has the activity of Ser/Thr protein kinase [5]. mTOR is considered as an important eukaryotic cell signal, coordinates cell growth and metabolism, affects transcription and protein synthesis, regulates cell apoptosis and autophagy $[6,7]$, and its stability affects the expression of cytokines in $\mathrm{T}$ cells and participates in immunosuppression [7-10]. Moreover, mTOR has become a new target for cancer treatment, and it also plays an important role in regulating diseases such as exercise, metabolism and nerves [11].

mTOR contains two complexes, mTORC1 and mTORC2 [4, 10, 12]. mTORC1 promotes protein synthesis primarily by phosphorylating two key effectors S6K1 and 4EBP [3, 13, 14]. Phosphorylation and activation of Akt may be the most important role for mTORC2 [12]. Once Akt is activated, it increases cell viability and promotes cell proliferation and growth through phosphorylation and co-suppression of several key substrates [15].

Knockdown of TMEM127 does not affect AKT activation. Similarly, the overexpression of TMEM127 did not alter AKT phosphorylation, suggesting that TMEM127 is not involved in the mTORC2 signaling pathway. In contrast, knockdown of TMEM127 increased the phosphorylation of 4EBP1 [3, 16]. Overexpression of TMEM127 reduces cell proliferation in cells. The signal path in which it participates is listed in Figure 1.

The lysate of TMEM127-mutant pheochromocytoma was collected and it was found that the phosphorylation level of S6K was increased compared with the tumor of normal adrenal medulla or without TMEM127 mutation. This phenomenon is the same as the role of NF1 in the mTOR pathway, and the phosphorylation of $\mathrm{S} 6 \mathrm{~K}$ is increased after mutation. Collectively, these

This article is published under the terms of the Creative Commons Attribution License 4.0 Author(s) retain the copyright of this article. Publication rights with Alkhaer Publications. Published at: http://www.ijsciences.com/pub/issue/2019-04/

DOI: 10.18483/ijSci.1985; Online ISSN: 2305-3925; Print ISSN: 2410-4477 
results indicate that TMEM127 is helpful in controlling mTORC1 signal transduction, and also demonstrates that TMEM127 acts as a tumor suppressor in tumors [1]. Its regulated signaling pathway is listed in Figure2.

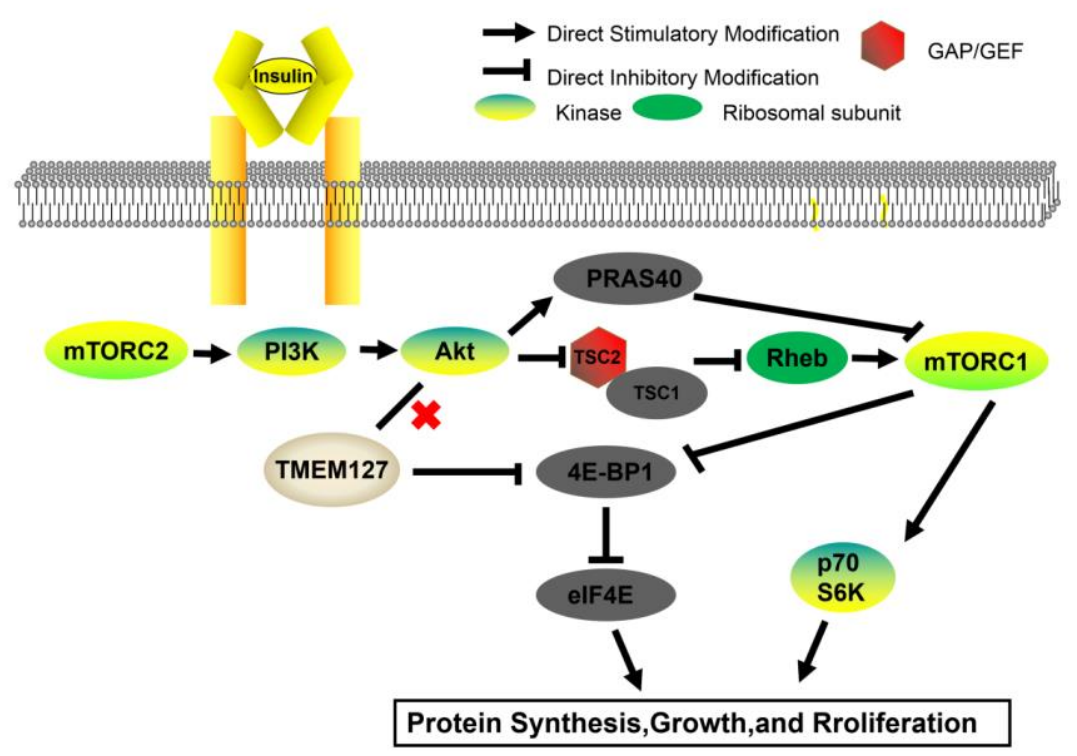

Figure1. TMEM127 is involved in the mTOR signaling pathway and regulates cell growth and proliferation. TMEM127 does not affect the expression of AKT in the mTORC2 signaling pathway. However, it can alter the phosphorylation of 4EBP1 in the mTORC1 signaling pathway. TMEM127 can regulate cell growth and proliferation in cells.

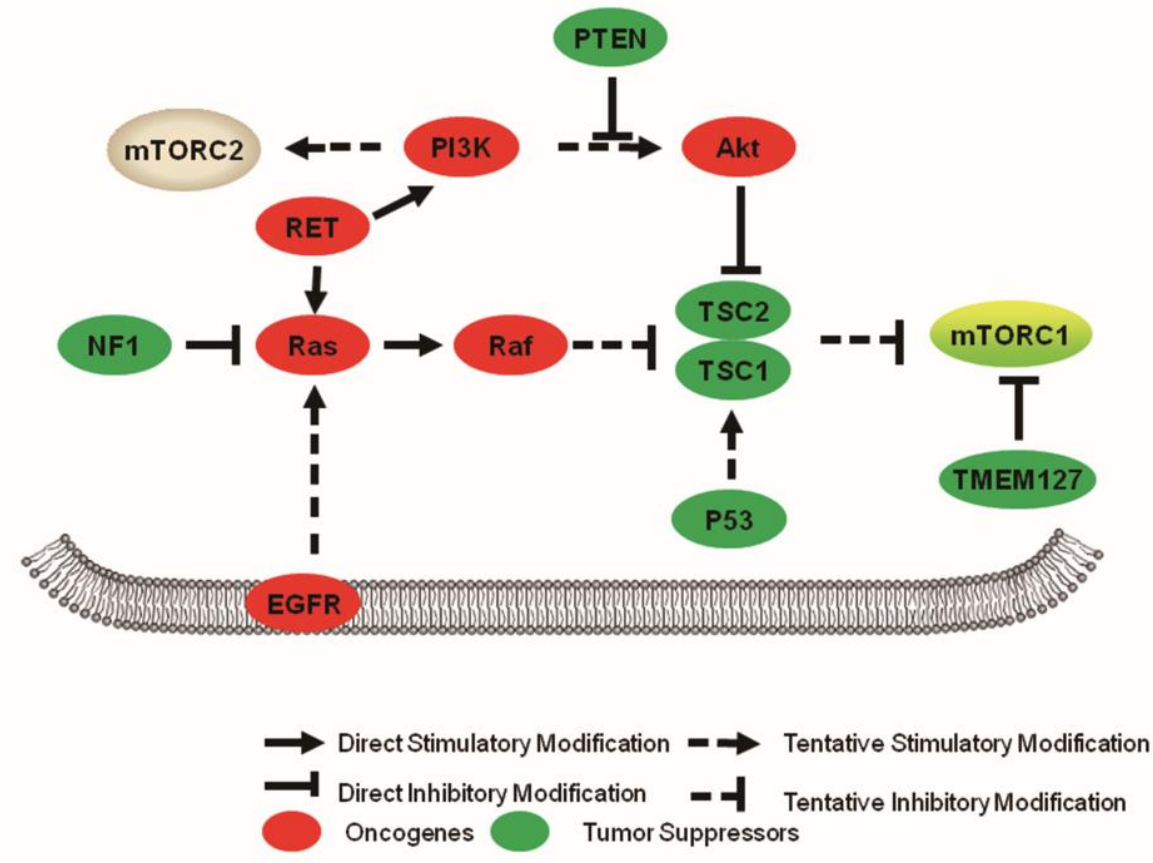

Figure2. TMEM127 acts as a tumor suppressor to inhibit the development of cancer by participating in the mTOR signaling pathway. The process by which the mTOR pathway is activated may contribute to tumorigenesis, and mTORC1 regulates mutations in many oncogenic pathways. As a tumor suppressor, TMEM127 can change the phosphorylation level of S6K in the mTOR pathway in tumor cells. 


\section{Disease associated with TMEM127}

Hereditary tumors have been an advancement in modern oncology as an irreplaceable source of novel cancer genes. Pheochromocytoma (PHEO) and paraganglioma (PGL) are rare neuroendocrine tumors[17]. Pheochromocytoma is a neuroendocrine tumor produced in chromaffin cells of the adrenal medulla. Paraganglioma is an extrarenal tumor called sympathetic nerve produced by chromaffin cells. Both pheochromocytoma and paraganglioma can secrete catecholamines [18]. For about two decades, several genes have been discovered that have an effect on PHEO and PGL. Mutations in these genes can lead to tumorigenesis depending on the mode of action. Clustering based on gene mutation patterns or transcriptomic features of these tumors is broadly classified into the following three categories:

The first category, related to the pseudo-hypoxia pathway, including mutations in PHD2,VHL, IDH, HIF2A, MDH2 , SDHA, SDHB, SDHC, SDHD, SDHAF2, FH and EPAS1 [19, 20].

The second class, associated with the MAP kinase signaling pathway and the mTor pathway, including mutations in RET, NF1, MAX, TMEM127 and HRAS.

Finally, in connection with the Wnt signaling pathway, mutations in MAML3 and CSDE1 affect the Wnt signaling pathway [21]. Detailed classification is shown in Figure3.

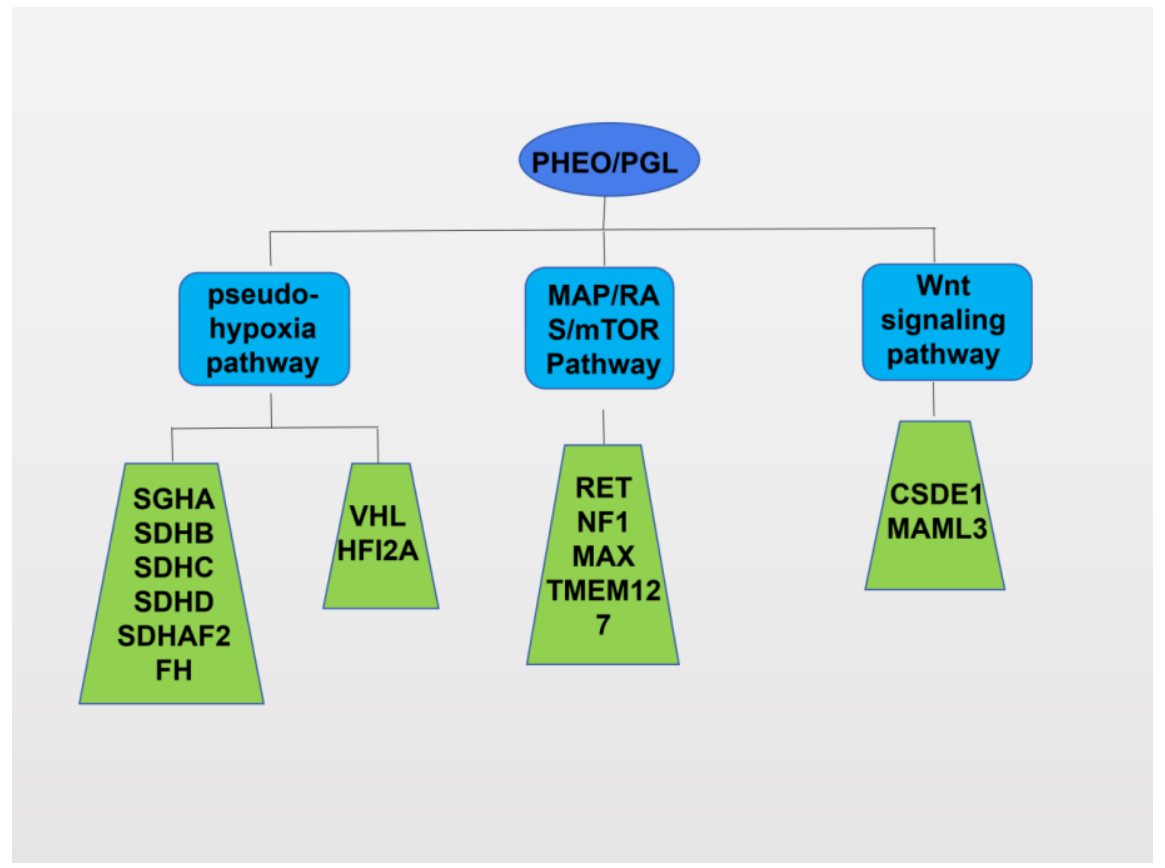

Figure 3. The subdivisions of molecular pathways of these genes in PHEO/PGL.

These different susceptibility genes belong to a variety of functional categories, as shown in Table 1. This review will focus on the gene TMEM127, summarizing new data on clinical phenotypes associated with its mutations and functions.

Pheochromocytoma and paraganglioma (PPGL) triggered by TMEM127 mutation has similar transcriptional characteristics to PPGL triggered by mutations in RET and NF1 genes [1, 22]. This finding is associated with the presence of high plasma adrenergic levels in patients with TMEM127 mutations and represents a potential for adrenaline production [23]. RET and NF1 gene mutations should be screened when patient adrenaline levels are significantly elevated. If the adrenaline levels caused by mutations in RET and NF1 are excluded, genetic screening for TMEM127 can be considered. It has been reported that VHL, RET, NF1, SDHA, FH and TMEM127 mutations are associated with biochemically silenced head and neck paraganglioma [24-32]. Therefore, TMEM127 can be used as a diagnostic indicator to detect pheochromocytoma and hereditary paraganglioma-pheochromocytoma syndrome. 


\begin{tabular}{|c|c|c|c|c|}
\hline Syndrome & $\begin{array}{l}\text { Predisposition } \\
\text { gene }\end{array}$ & Tumor types & $\begin{array}{c}\text { Tumor gene } \\
\text { type }\end{array}$ & Gene function \\
\hline $\begin{array}{l}\text { MEN2A and } \\
\text { MEN2B }\end{array}$ & RET & $\begin{array}{c}\text { Pheochromocytoma; thyroid } \\
\text { (medullary); parathyroid } \\
\text { (hyperplasia or adenoma) }\end{array}$ & Oncogene & Kinase receptor \\
\hline VHL & VHL & $\begin{array}{l}\text { Pheochromocytoma or } \\
\text { paraganglioma; clear } \\
\text { cell-renal cell carcinoma; } \\
\text { hemangioblastomas of } \\
\text { central nervous system }\end{array}$ & $\begin{array}{l}\text { Tumor } \\
\text { suppressor } \\
\text { gene }\end{array}$ & Ubiquitin ligase \\
\hline $\begin{array}{l}\text { Neurofibromatosi } \\
\text { s } \\
\text { type } 1\end{array}$ & NF1 & $\begin{array}{l}\text { Neurofibromas; malignant } \\
\text { peripheral nerve sheath } \\
\text { tumors; gliomas, leukemia; } \\
\text { pheochromocytoma }\end{array}$ & $\begin{array}{l}\text { Tumor } \\
\text { suppressor } \\
\text { gene }\end{array}$ & Ras-GAP \\
\hline $\begin{array}{c}\text { Familial } \\
\text { pheochromocyto } \\
\text { ma } 2 q\end{array}$ & TMEM127 & $\begin{array}{l}\text { Pheochromocytoma; Renal } \\
\text { cell carcinoma }\end{array}$ & $\begin{array}{l}\text { Tumor } \\
\text { suppressor } \\
\text { gene }\end{array}$ & $\begin{array}{c}\text { Endosomal } \\
\text { trafficking; } \\
\text { mTOR regulation }\end{array}$ \\
\hline $\begin{array}{l}\text { Familial } \\
\text { paraganglioma } \\
\text { type } 1\end{array}$ & SDHD & $\begin{array}{c}\text { Paraganglioma (sympathetic } \\
\text { and } \\
\text { parasympathetic); } \\
\text { pheochromocytoma }\end{array}$ & $\begin{array}{l}\text { Tumor } \\
\text { suppressor } \\
\text { gene }\end{array}$ & $\begin{array}{l}\text { SDH, } \\
\text { mitochondria } \\
\text { respiratory } \\
\text { chain; tricyclic } \\
\text { acid cycle }\end{array}$ \\
\hline $\begin{array}{c}\text { Familial } \\
\text { paraganglioma } \\
\text { type } 2\end{array}$ & SDHAF2 & $\begin{array}{c}\text { Paraganglioma } \\
\text { (parasympathetic) }\end{array}$ & $\begin{array}{l}\text { Tumor } \\
\text { suppressor } \\
\text { gene }\end{array}$ & $\begin{array}{l}\text { SDH, } \\
\text { mitochondria } \\
\text { respiratory } \\
\text { chain; tricyclic } \\
\text { acid cycle }\end{array}$ \\
\hline $\begin{array}{c}\text { Familial } \\
\text { paraganglioma } \\
\text { type } 3\end{array}$ & SDHC & $\begin{array}{l}\text { Paraganglioma } \\
\text { (parasympathetic, } \\
\text { rarely sympathetic) }\end{array}$ & $\begin{array}{l}\text { Tumor } \\
\text { suppressor } \\
\text { gene }\end{array}$ & $\begin{array}{l}\text { SDH, } \\
\text { mitochondria } \\
\text { respiratory } \\
\text { chain; tricyclic } \\
\text { acid cycle }\end{array}$ \\
\hline $\begin{array}{c}\text { Familial } \\
\text { paraganglioma } \\
\text { type } 4\end{array}$ & SDHB & $\begin{array}{c}\text { Paraganglioma (sympathetic } \\
\text { and } \\
\text { parasympathetic); } \\
\text { pheochromocytoma; renal } \\
\text { cell } \\
\text { carcinoma }\end{array}$ & $\begin{array}{l}\text { Tumor } \\
\text { suppressor } \\
\text { gene }\end{array}$ & $\begin{array}{l}\text { SDH, } \\
\text { mitochondria } \\
\text { respiratory } \\
\text { chain; tricyclic } \\
\text { acid cycle }\end{array}$ \\
\hline
\end{tabular}

Table 1. Familial syndrome is associated with pheochromocytoma and/or paraganglioma. The clinical findings and syndromes of eight susceptibility genes for pheochromocytoma are associated with the type of tumor. 


\section{Clinical manifestation and monitoring of TMEM127}

Their prevalence has been estimated at $1-2 \%$ in patients with PHEO or PGL [23]. Transmission of the disease is autosomal dominant. Mutations of TMEM127 induce almost exclusively the development of PHEO (in $96 \%$ of cases), benign (90 to $98 \%$ of cases) and bilateral in almost $40 \%$ of cases. The profile secretory associates metanephrines and normetanephrines [23, 28]. One-third of patients have a phenotype of sporadic benign PHEO [1, 23]. Therefore, the age of diagnosis is the same as that of sporadic PHEO without genetic causes, in the fourth decade (average of 43 years), and the diagnosis time is 20 to 65 years. The onset of PHEO may precede adrenal hyperplasia [33]. Two patients with rare PGL (abdominal and cervix) cases were also reported [28]. It has also been linked to kidney cancer [34]. Although the age of genetic testing has been established around the age of 15, monitoring arrangements remain controversial [33]. Through simple clinical monitoring, Toledo reported the discovery of PHEO in 11/34 people in the same household. The youngest case is 22 years old, and the youngest symptomatic patient is 10 years old [33]. The study calculated a penetrance rate of $0 \% 20$ years ago, $3 \%$ between 21 and 30 years, $15 \%$ between 31 and 40 years, $24 \%$ between 41 and 50 years, and 32\% from 51 to 65 years. These data were confirmed, and only a quarter of these patients had a family history.

Different authors recommend different monitoring: Toledo et al. recommend follow-up of healthy carriers based on clinical examinations, and only perform clinical examinations when calls occur. Favier et al. recommend the same surveillance as MAX variant relatives [35], Bausch et al. advocated systematically achieving head and neck MRI (unspecified achievement speed) [36].

In a recent case report, they analyzed a patient who had congenital tricuspid atresia through Fontan surgery. The patient was hospitalized for hypertensive crisis and breathing difficulties. An increase in norepinephrine (NA) and its metabolite levels was detected by testing. No other symptoms associated with excess catecholamines were found. After open adrenalectomy, histopathological examination confirmed pheochromocytoma. However, no genetic mutations (such as RET, TMEM127, MAX, SDHD, SDHC, SDHB, SDHAF2, SDHA and VHL) were found by screening [37].

In another case report, a man was diagnosed with both pheochromocytoma, paraganglioma, and papillary thyroid carcinoma, but it was found that the previously known related genes were not mutated. Gene mutations such as EGLN1, FH, KIF1B, MEN1, NF1, RET, SDHAF2, SDHC, SDHD, TMEM127, VHL and SDHA were all negative. In the case, it is not clear whether the occurrence of paraganglioma/pheochromocytoma/thyroid papillary carcinoma is accidental or caused by underlying genetic susceptibility [38].

Therefore, whether the combination of paraganglioma/pheochromocytoma/thyroid papillary carcinoma is coincidental or caused by an unknown gene mutation, it cannot be ruled out.

\section{Summary and outlook}

In short, in the past 10 to 20 years, more and more models and studies have emerged in this field, and it is of great significance to study their natural history and conduct preclinical testing. Genetically based monitoring provides an important basis for clinical care in these patients, providing valuable opportunities for early detection and treatment of disease. In addition, there are still urgent clinical needs for how to improve the treatment of patients with pheochromocytoma/paraganglioma.

At present, the research on the gene TMEM127 is still not very thorough, and the relevant reports are not comprehensive, and further exploration of its function and mechanism is needed. Although recommendations have been made for genetic screening and monitoring methods for asymptomatic patients with TMEM127 gene mutations, there is still disharmony at the international level, requiring further clinical research and monitoring to address these recommendations not only on the basis of objective evidence, it is even more necessary to solve these problems in real life.

\section{Conflict of interest}

The authors declare that they have no conflict of interest with the contents of this article.

\section{Acknowledgements}

This work was funded by National Natural Science Foundation of China (31701175), China Postdoctoral Science Foundation (2017M612188) and Natural Science Foundation of Shandong Province (ZR2017BC003)

\section{References}

1. Qin, Y., et al., Germline mutations in TMEM127 confer susceptibility to pheochromocytoma. Nat Genet, 2010. 42(3): p. 229-33.

2. Yao, L., et al., Spectrum and prevalence of FP/TMEM127 gene mutations in pheochromocytomas and paragangliomas. Jama, 2010. 304(23): p. 2611-9.

3. Laplante, M. and D.M. Sabatini, mTOR signaling at a glance. J Cell Sci, 2009. 122(Pt 20): p. 3589-94.

4. Kwiatkowski, D.J. and B.D. Manning, Tuberous sclerosis: a GAP at the crossroads of multiple signaling pathways. Hum Mol Genet, 2005. 14 Spec No. 2: p. R251-8.

5. Fraenkel, M., et al., mTOR inhibition by rapamycin prevents beta-cell adaptation to hyperglycemia and exacerbates the metabolic state in type 2 diabetes. Diabetes, 2008. 57(4): p. 945-57.

6. Kim, D.H., et al., mTOR interacts with raptor to form a 
nutrient-sensitive complex that signals to the cell growth machinery. Cell, 2002. 110(2): p. 163-75.

7. Weichhart, T., M. Hengstschlager, and M. Linke, Regulation of innate immune cell function by mTOR. Nat Rev Immunol, 2015. 15(10): p. 599-614.

8. $\quad$ Rao, R.R., et al., The mTOR kinase determines effector versus memory $C D 8+T$ cell fate by regulating the expression of transcription factors T-bet and Eomesodermin. Immunity, 2010. 32(1): p. 67-78

9. Rao, R.R., Q. Li, and P.A. Shrikant, Fine-tuning CD8(+) T cell functional responses: $m$ TOR acts as a rheostat for regulating CD8(+) T cell proliferation, survival and differentiation? Cell Cycle, 2010. 9(15): p. 2996-3001.

10. Thomson, A.W. H.R. Turnquist, and G. Raimondi, Immunoregulatory functions of mTOR inhibition. Nat Rev Immunol, 2009. 9(5): p. 324-37.

11. Huijts, C.M., et al., Immunological effects of everolimus in patients with metastatic renal cell cancer. Int J Immunopathol Pharmacol, 2017. 30(4): p. 341-352.

12. Sarbassov, D.D., et al., Phosphorylation and regulation of $A k t / P K B$ by the rictor-mTOR complex. Science, 2005. 307(5712): p. 1098-101.

13. Ma, X.M. and J. Blenis, Molecular mechanisms of mTOR-mediated translational control. Nat Rev Mol Cell Biol, 2009. 10(5): p. 307-18.

14. Araki, K., et al., mTOR regulates memory CD8 T-cell differentiation. Nature, 2009. 460(7251): p. 108-12.

15. Bayascas, J.R. and D.R. Alessi, Regulation of Akt/PKB Ser473 phosphorylation. Mol Cell, 2005. 18(2): p. 143-5.

16. Yang, H.W., et al., mTORC2 facilitates endothelial cell senescence by suppressing Nrf2 expression via the Akt/GSK-3beta/C/EBPalpha signaling pathway. Acta Pharmacol Sin, 2018. 39(12): p. 1837-1846.

17. Lam, A.K., Update on Adrenal Tumours in 2017 World Health Organization (WHO) of Endocrine Tumours. Endocr Pathol, 2017. 28(3): p. 213-227.

18. Manger, W.M., An overview of pheochromocytoma: history, current concepts, vagaries, and diagnostic challenges. Ann N Y Acad Sci, 2006. 1073: p. 1-20.

19. Dahia, P.L., et al., A HIFlalpha regulatory loop links hypoxia and mitochondrial signals in pheochromocytomas. PLoS Genet, 2005. 1(1): p. 72-80.

20. Favier, J. and A.P. Gimenez-Roqueplo, [Genetics of paragangliomas and pheochromocytomas]. Med Sci (Paris), 2012. 28(6-7): p. 625-32

21. Crona, J., D. Taieb, and K. Pacak, New Perspectives on Pheochromocytoma and Paraganglioma: Toward a Molecular Classification. Endocr Rev, 2017. 38(6): p. 489-515.

22. Burnichon, N., et al., Integrative genomic analysis reveals somatic mutations in pheochromocytoma and paraganglioma. Hum Mol Genet, 2011. 20(20): p. 3974-85.

23. Abermil, N., et al., TMEM127 screening in a large cohort of patients with pheochromocytoma and/or paraganglioma. J Clin
Endocrinol Metab, 2012 97(5): p. E805-9.

24. Korpershoek, E., et al., SDHA immunohistochemistry detects germline SDHA gene mutations in apparently sporadic paragangliomas and pheochromocytomas. J Clin Endocrinol Metab, 2011. 96(9): p. E1472-6.

25. Castro-Vega, L.J., et al., Germline mutations in FH confer predisposition to malignant pheochromocytomas and paragangliomas. Hum Mol Genet, 2014. 23(9): p. 2440-6.

26. Bayley, J.P., et al., SDHAF2 mutations in familial and sporadic paraganglioma and phaeochromocytoma. Lancet Oncol, 2010. 11(4): p. 366-72.

27. Kunst, H.P., et al., SDHAF2 (PGL2-SDH5) and hereditary head and neck paraganglioma. Clin Cancer Res, 2011. 17(2): p. 247-54.

28. Neumann, H.P., et al., Germline mutations of the TMEM127 gene in patients with paraganglioma of head and neck and extraadrenal abdominal sites. J Clin Endocrinol Metab, 2011. 96(8): p. E1279-82

29. Boedeker, C.C., et al., Head and neck paragangliomas in von Hippel-Lindau disease and multiple endocrine neoplasia type 2. J Clin Endocrinol Metab, 2009. 94(6): p. 1938-44.

30. DeAngelis, L.M., et al., Multiple paragangliomas in neurofibromatosis: a new neuroendocrine neoplasia. Neurology, 1987. 37(1): p. 129-33

31. Gaal, J., et al., Parasympathetic paragangliomas are part of the Von Hippel-Lindau syndrome. J Clin Endocrinol Metab, 2009. 94(11): p. 4367-71.

32. Maier, W., N. Marangos, and R. Laszig, Paraganglioma as a systemic syndrome: pitfalls and strategies. J Laryngol Otol, 1999. 113(11): p. 978-82.

33. Toledo, S.P., et al., Penetrance and clinical features of pheochromocytoma in a six-generation family carrying a germline TMEM127 mutation. J Clin Endocrinol Metab, 2015. 100(2): p. E308-18.

34. Hernandez, K.G., et al., Familial pheochromocytoma and renal cell carcinoma syndrome: TMEM127 as a novel candidate gene for the association. Virchows Arch, 2015. 466(6): p. 727-32.

35. Favier, J., L. Amar, and A.P. Gimenez-Roqueplo, Paraganglioma and phaeochromocytoma: from genetics to personalized medicine. Nat Rev Endocrinol, 2015. 11(2): p. 101-11.

36. Bausch, B., et al., Clinical Characterization of the Pheochromocytoma and Paraganglioma Susceptibility Genes SDHA, TMEM127, MAX, and SDHAF2 for Gene-Informed Prevention. JAMA Oncol, 2017. 3(9): p. 1204-1212.

37. Aresta, C., et al., Pheochromocytoma in Congenital Cyanotic Heart Disease. Case Rep Endocrinol, 2018. 2018: p. 2091257.

38. Rasquin, L., et al., Simultaneous Pheochromocytoma, Paraganglioma, and Papillary Thyroid Carcinoma without Known Mutation. Case Rep Endocrinol, 2018. 2018: p. 6358485 . 